\title{
Effect of Resveratrol on the Development of Porcine Embryos Produced In Vitro
}

\author{
Kiho LEE ${ }^{1)}$, Chunmin WANG ${ }^{1)}$, John M CHAILLE ${ }^{1)}$ and Zoltan MACHATY1) \\ ${ }^{1)}$ Department of Animal Sciences, Purdue University, West Lafayette, IN 47907, USA
}

\begin{abstract}
The effects of resveratrol (a phytoalexin with a wide variety of pharmacological activities) on pig embryos produced by parthenogenesis and/or in vitro fertilization have been investigated. First, parthenogenetic embryos were generated and cultured in PZM-3 medium supplemented with various amounts of resveratrol $(0,0.05,0.1,0.5,1.0$ and $25 \mu \mathrm{M}$ final concentrations). In the presence of $0.5 \mu \mathrm{M}$ resveratrol a significantly higher percentage of parthenogenetic embryos reached the blastocyst stage by day 7 compared to non-treated control ( $43.5 \pm 6.3 \%$ vs. $33.0 \pm 5.4 \%$; $P<0.05)$. The total cell number of blastocysts also increased as a result of incubation with $0.5 \mu \mathrm{M}$ resveratrol; the difference was statistically significant between treated and non-treated embryos on day 5 of culture $(35.8 \pm 0.9$ vs. $32.1 \pm 1.1 ; \mathrm{P}<0.05)$. Resveratrol incubation affected the expression levels of apoptosis-related genes in parthenogenetic blastocysts: the level of Bax transcripts was similar but lower expression of Bcl-2 and Caspase- 3 was observed in embryos treated with $0.5 \mu \mathrm{M}$ resveratrol when compared to control blastocysts $(\mathrm{P}<0.05)$. The results of the TUNEL assay were similar in blastocysts developing with or without resveratrol supplementation. In addition, when embryos produced by in vitro fertilization were incubated with $0.5 \mu \mathrm{M}$ resveratrol, the treatment led to higher frequencies of blastocyst formation $(8.6 \%$ vs. $13.3 \%)$ and elevated total cell numbers $(37.1 \pm 2.4$ vs. $43.2 \pm 1.7)$ by the end of the 7 -day culture period $(\mathrm{P}<0.05)$. The results indicate that $0.5 \mu \mathrm{M}$ resveratrol during culture has a positive effect on early embryonic development of porcine embryos.
\end{abstract}

Key words: Development, Embryo, Pig, Resveratrol

(J. Reprod. Dev. 56: 330-335, 2010)

E mbryo culture is valuable in the study of preimplantation embryonic development and is indispensable for the in vitro production of transferable embryos. In spite of significant improvements in the culture conditions, the development of in vitro-produced embryos is still suboptimal [1]. Because the preimplantation embryo is extremely sensitive to environmental factors, deficiencies in culture conditions often lead to aberrant embryo development that manifest in lower frequency of blastocyst formation and lower cell numbers and can affect fetal as well as postnatal life [2]. Modifications in the culture system can potentially improve the development of the cultured embryos.

Resveratrol (3,4',5-trihydroxystilbene) is a phytoalexin identified in more than 70 plant species including grapes, plums, and peanuts [3]. Its biological function is to protect the plant in case of a parasitic attack or environmental stress [4]. Originally, the search for plant-derived compounds with pharmacological properties identified resveratrol as a blocker of enzymes involved in arachidonate metabolism [5] and later, an inhibitor of partially purified kinases [6]. Based on its ability to block the cyclooxygenase COX1 resveratrol was suggested to have anticancer properties and it was demonstrated that topic application of resveratrol decreased tumorigenesis in a mouse skin cancer model [7].

Resveratrol was later shown to exert a wide variety of pharmacological activities ranging from anti-inflammatory effects to

Received: September 30, 2009

Accepted: January 26, 2010

Published online in J-STAGE: February 18, 2010

(C)2010 by the Society for Reproduction and Development

Correspondence: Z Machaty (e-mail: zmachaty@purdue.edu) immunomodulation and cardioprotection [for recent reviews see 8, 9]. It is able to influence the expression of a wide range of genes that are related to DNA synthesis, cell cycle, proliferation, stress responses, and apoptosis. In addition, via the activation of sirtuin proteins, a class of histone deacetylases with a role in lifespan determination, resveratrol was shown to increase lifespan in yeast [10] as well as C. elegans, Drosophila [11] and mice [12]. These various effects of resveratrol are explained by the fact that resveratrol targets many components of intracellular signaling pathways by modulating a great number of enzymes including kinases, lipoand cyclooxygenases, sirtuins, and transcription factors [8].

When cultured cells were exposed to resveratrol diverse results were obtained depending on the concentration it was applied. In human tumor cells resveratrol at high concentrations (10.0-100.0 $\mu \mathrm{g} / \mathrm{ml}$ ) induced apoptosis and decreased mitotic activity [13] while low doses of resveratrol $(0.1-1.0 \mu \mathrm{g} / \mathrm{ml})$ enhanced cell proliferation [14]. Similarly, in osteoblastic MC3T3-E1 cells resveratrol dose-dependently stimulated proliferation and differentiation [15]. Because of its ability to positively influence a number of cellular processes in cultured cells we hypothesized that resveratrol may also be beneficial for the development of preimplantation embryos under in vitro conditions. The aim of this study was to investigate the effect of resveratrol on the early development of parthenogenetic and IVF embryos using the pig as a model.

\section{Materials and Methods}

Unless stated otherwise, all chemicals were obtained from Sigma-Aldrich Chemical (St. Louis, MO, USA). 
Table 1. Primer sequences used for real-time RT-PCR

\begin{tabular}{|c|c|c|c|c|}
\hline Gene & Primer sequences (5'-3’) & $\begin{array}{l}\text { Product size } \\
\text { (bp) }\end{array}$ & $\begin{array}{c}\text { Annealing } \\
\text { temperature (C) }\end{array}$ & $\begin{array}{c}\text { GenBank } \\
\text { accession number }\end{array}$ \\
\hline \multirow[t]{2}{*}{ Bax } & F: AAGCGCATTGGAGATGAACT & & & \\
\hline & R: CGATCTCGAAGGAAGTCCAG & 251 & 60 & AJ606301 \\
\hline \multirow[t]{2}{*}{ Bcl-2 } & F: ACTGAATGCCCTCCGGTACC & & & \\
\hline & R: ATCCCCATGGCTGCAGTGAA & 80 & 60 & NM214285 \\
\hline \multirow[t]{2}{*}{ Caspase-3 } & F: ACACGCCATGTCATCTTCAGTCC & & & \\
\hline & R: TTCATAATTCAGGCCTGCCGAG & 81 & 60 & NM214131 \\
\hline \multirow[t]{2}{*}{ GAPDH } & F: ACATCAAGAAGGTGGTGAAG & & & \\
\hline & R: ATTGTCGTACCAGGAAATGAG & 151 & 52 & AF017079 \\
\hline
\end{tabular}

\section{Oocytes}

Ovaries of prepubertal Large White gilts were collected at an abattoir and transported to the laboratory in physiological saline maintained at $\sim 30 \mathrm{C}$. The follicular fluid was aspirated from medium size (3 to 6-mm) follicles using a syringe attached to a 20gauge hypodermic needle and collected in a 50-ml centrifuge tube. Oocytes with intact cumulus investment and evenly dark cytoplasm were selected and washed in Hepes-buffered Tyrode's lactate (TLHepes) medium. They were then matured in TCM-199 medium (50 oocytes per $500 \mu \mathrm{l}$ of medium) supplemented with $0.1 \mathrm{mg} / \mathrm{ml}$ cysteine, $0.5 \mathrm{IU} / \mathrm{ml} \mathrm{LH}, 0.5 \mathrm{IU} / \mathrm{ml} \mathrm{FSH}$ and $10 \mathrm{ng} / \mathrm{ml}$ epidermal growth factor at $39 \mathrm{C}$ in $5 \% \mathrm{CO}_{2}$ in air. After $42 \mathrm{~h}$, the oocytes were collected and the surrounding cumulus cells were removed by vortexing in $0.1 \%$ hyaluronidase.

\section{Oocyte activation}

In order to generate embryos for the studies porcine oocytes were parthenogenetically activated by electroporation. For this purpose mature oocytes were transferred into electroporation medium (300 mM mannitol, $0.1 \mathrm{mM} \mathrm{CaCl}_{2}, 0.1 \mathrm{mM} \mathrm{MgSO}_{4}, 0.5$ $\mathrm{mM}$ Hepes, $0.01 \mathrm{mg} / \mathrm{ml}$ BSA) between two stainless steel electrodes of the electroporation chamber. The oocytes were then activated by applying two direct current electric pulses $(120 \mathrm{~V} / \mathrm{mm}$, $60 \mu$ sec each, 1 sec apart) followed by an incubation with $10 \mu \mathrm{g} / \mathrm{ml}$ cycloheximide and $7.5 \mu \mathrm{g} / \mathrm{ml}$ cytochalasin B, for $5 \mathrm{~h}$. Activated oocytes (in groups of 10) were then placed in $20 \mu \mathrm{l}$ drops of Porcine Zygote Medium 3 (PZM-3) containing various concentrations of resveratrol $(0,0.1,0.5,1.0,25 \mu \mathrm{M}$; Sigma-Aldrich catalog \# R5010) covered with mineral oil. Resveratrol was dissolved in dimethyl sulfoxide (DMSO) and kept frozen as a stock (84 mM) until it was added to the medium. The dishes were incubated in a humidified incubator at $39 \mathrm{C}$ under $5 \% \mathrm{CO}_{2}$ in air.

\section{In vitro fertilization}

Mature oocytes were rinsed in a modified Tris-buffered medium consisting of $113.1 \mathrm{mM} \mathrm{NaCl}, 3 \mathrm{mM} \mathrm{KCl}, 7.5 \mathrm{mM} \mathrm{CaCl}_{2} \times 2 \mathrm{H}_{2} \mathrm{O}$, $20 \mathrm{mM}$ Tris (crystallized free base; Fisher Scientific, Fair Lawn, NJ, U.S.A.), $11 \mathrm{mM}$ glucose, $5 \mathrm{mM}$ sodium pyruvate, $0.1 \%$ BSA, and $1 \mathrm{mM}$ caffeine [16]. Groups of 30 to 35 oocytes were placed into $50 \mu$ droplets of the same medium covered with warm mineral oil. Fresh semen was collected from a Large White boar, diluted in Modena extender and stored at $17 \mathrm{C}$ for up to three days. Prior to use, the extended semen was washed three times by centrifugation at $1,900 \mathrm{~g}$ for $4 \mathrm{~min}$ in Dulbecco's phosphate buffered saline (DPBS; without calcium and magnesium) containing $0.1 \%$ BSA, $75 \mu \mathrm{g} / \mathrm{ml}$ potassium penicillin $\mathrm{G}$, and $50 \mu \mathrm{g} / \mathrm{ml}$ streptomycin sulfate (pH 7.2, $39 \mathrm{C})$. The final sperm pellet was diluted with the modified Tris-buffered medium described above. The sperm suspension at a final concentration of $5 \times 10^{5}$ cells $/ \mathrm{ml}$ was added to each $50 \mu \mathrm{l}$ droplet containing the oocytes. The gametes were coincubated for $5 \mathrm{~h}$ at $39 \mathrm{C}$ in an atmosphere of $5 \% \mathrm{CO}_{2}$ in air; potential zygotes were then transferred to PZM-3 medium for culture.

\section{Quantitative real-time PCR}

Parthenogenetic blastocysts were collected on day 7 from the control as well as the $0.5 \mu \mathrm{M}$ resveratrol-treated groups (40 blastocysts from each group generated by a single round of oocyte activation). They were rinsed three times in PBS containing 0.1 $\mathrm{mg} / \mathrm{ml}$ polyvinyl alcohol (PVA) and $0.1 \mathrm{mg} / \mathrm{ml}$ diethylpyrocarbonate (DEPC) and then placed into $100 \mu \mathrm{l}$ lysis/binding buffer consisting of $100 \mathrm{mM}$ Tris- $\mathrm{HCl}, 500 \mathrm{mM} \mathrm{LiCl}, 10 \mathrm{mM}$ EDTA, 1\% LiDS and $5 \mathrm{mM}$ dithiothereitol (DTT). Messenger RNA was then extracted from the lysed embryos by the Dynabeads mRNA direct kit (Invitrogen Corporation; Carlsbad, CA, USA) according to the manufacturer's protocol. Magnetic beads with mRNA attached were re-suspended in $20 \mu \mathrm{l}$ of reverse transcription (RT) reaction mix consisting of $4 \mu \mathrm{l}$ of $5 \mathrm{X}$ iScript Reaction Mix, $1 \mu \mathrm{l}$ of iScript Reverse Transcriptase and $15 \mu$ of nuclease free water (iScript ${ }^{\mathrm{TM}}$ cDNA Synthesis Kit, Bio-Rad; Hercules, CA, USA). Reverse transcription reactions were carried out in the presence of the Dynabeads under conditions of $25 \mathrm{C}$ for $5 \mathrm{~min}$ and $42 \mathrm{C}$ for $30 \mathrm{~min}$ followed by $85 \mathrm{C}$ for $5 \mathrm{~min}$. The cDNA was then used for real-time PCR. Primers for real-time PCR were designed (in the case of Bcl2 and Caspase-3) or obtained from previous reports (Bax, [17]); the GAPDH primers were received as a generous gift from Dr. Rebecca Krisher of University of Illinois at Urbana-Champaign. The primer sequences are shown in Table 1 . Each reaction mixture consisted of $2.5 \mu \mathrm{l}$ of cDNA, $5 \mu$ l each of forward $(1 \mu \mathrm{M})$ and reverse $(1 \mu \mathrm{M})$ primers, and $12.5 \mu$ SybrGreen PCR Master Mix (Bio-Rad) in a total reaction volume of $25 \mu$ in 96-well plates. PCR reactions were performed in three replicates; for each replicate cDNA from a single pool of embryos was sub-divided to amplify all genes during the same PCR assay. As a negative control, an RT reaction in which the reverse transcriptase enzyme was 
replaced with nuclease-free water was used as a template. PCR was performed on a MyiQ single color real-time thermal cycler (Bio-Rad). The program used for amplification included an initial temperature of $94 \mathrm{C}$ for $5 \mathrm{~min}$ followed by 40 cycles of $5 \mathrm{sec}$ at 94 $\mathrm{C}, 30 \mathrm{sec}$ at $60 \mathrm{C}$ ( $52 \mathrm{C}$ for GAPDH), and $30 \mathrm{sec}$ at $72 \mathrm{C}$. Real time fluorescence data were collected during the extension time. A melting curve was produced to verify the identity of each PCR product; successful amplification was further confirmed by separating the amplicons by agarose gel electrophoresis. In the first replicate transcripts were also cloned and sequenced to confirm product identity.

Transcript levels of Bax, Bcl-2, and Caspase-3 were quantified using the relative quantification method based on comparative threshold cycles $\left(C_{t}\right)$ values. The transcript abundance of each gene was determined relative to that of the internal control gene $\mathrm{GAPDH}$. The $\mathrm{C}_{\mathrm{t}}$ value, i.e. the cycle number during the log-linear phase when the amount of amplified product rose above background level was determined for each gene and subtracted from that of the GAPDH gene to obtain $\Delta \mathrm{C}_{\mathrm{t}}$. Control group $\mathrm{C}_{\mathrm{t}}$ values served as calibrators and were used subsequently to obtain $\Delta \Delta \mathrm{C}_{\mathrm{t}}$ values. Fold differences in transcript abundance were calculated for Bax, Bcl-2, and Caspase-3 assuming an amplification efficiency of $100 \%$ and using the equation $2{ }^{-} \Delta \mathrm{CCT}$. To verify that amplification efficiencies were similar for each amplicon a validation test was run prior to the experiment.

\section{TUNEL assay}

At the end of the 7-day culture period, parthenogenetic blastocysts were fixed in $4 \%$ paraformaldehyde overnight at $4 \mathrm{C}$ and permeabilized in $0.1 \%$ Triton $\mathrm{X}-100$ in $0.1 \%$ sodium citrate for 2 min. The activations were performed in three replications to produce the blastocysts for the assay. The embryos were then incubated for $1 \mathrm{~h}$ at $39 \mathrm{C}$ in a TUNEL reaction medium (In Situ Cell Death Detection Kit, Roche Applied Science; Indianapolis, IN, USA) that specifically labels the exposed 3'-OH ends of single- strand DNA breaks (a process associated with late stage apoptosis and necrosis) with the fluorochrome FITC. After rinsing in PBS, nuclei of the labeled embryos were stained with $5 \mu \mathrm{g} / \mathrm{ml}$ Hoechst 33342 for $10 \mathrm{~min}$. The embryos were then mounted on microscope slides and examined under UV light using an epifluorescence microscope. Nuclei showing green fluorescence were counted as apoptotic/necrotic; the total number of nuclei per blastocysts was determined based on Hoechst 33342 staining. Two-cell embryos collected after 1 day of culture were stained as negative controls; for positive control blastocysts treated with DNase I were used.

\section{Statistical analysis}

The frequencies of blastocyst formation in the treatment groups were compared by the Chi-square test. Total cell numbers and results of the TUNEL assay were compared by Student's $t$-test. Differences in gene expression were analyzed by ANOVA; differences at $\mathrm{P}<0.05$ were considered significant.

\section{Results}

In preliminary experiments we determined the most effective dose of resveratrol. These experiments (a total of 8 replications) demonstrated that resveratrol had a distinct dose-dependent effect on the development of parthenogenetic porcine embryos (Table 2). Blastocyst formation in the control group was $33.0 \%$ while in the presence of $25 \mu \mathrm{M}$ resveratrol only $4.5 \%$ of the embryos formed blastocysts. Incubation with $0.5 \mu \mathrm{M}$ resveratrol had no effect and blastocyst development in the presence of $0.1 \mu \mathrm{M}$ resveratrol tended to be higher compared to the control group. Based on these data we then selected the concentration of $0.5 \mu \mathrm{M}$ as our resveratrol treatment and investigated its effect on embryos compared to those that developed in the absence of resveratrol. When parthenogenetic embryos were cultured in the presence of $0.5 \mu \mathrm{M}$ resveratrol, embryonic development improved significantly compared to the control group (four replications; Table 3). As a result of resveratrol

Table 2. Effect of resveratrol on parthenogenetic blastocyst formation by the end of the 7 day culture period

\begin{tabular}{lcc}
\hline Resveratrol concentration & No. of parthenotes & No. of blastocysts (\% \pm S.E.M.) \\
\hline $0 \mu \mathrm{M}$ (control) & 312 & $103(33.0 \pm 5.4)$ \\
$0.05 \mu \mathrm{M}$ & 252 & $83(32.9 \pm 6.7)$ \\
$0.1 \mu \mathrm{M}$ & 203 & $81(39.9 \pm 3.8)$ \\
$0.5 \mu \mathrm{M}$ & 301 & $131(43.5 \pm 6.3)$ \\
$1.0 \mu \mathrm{M}$ & 195 & $61(31.3 \pm 4.9)$ \\
$25 \mu \mathrm{M}$ & 89 & $4(4.5 \pm 1.2)$ \\
\hline
\end{tabular}

Table 3. Cleavage, blastocyst formation and total cell number (mean \pm S.E.M.) in embryos developed with or without resveratrol supplementation

\begin{tabular}{|c|c|c|c|c|c|}
\hline \multirow[t]{2}{*}{ Group } & \multirow{2}{*}{$\begin{array}{c}\text { Cleaved } \\
\text { embryos } \\
\text { (\% } \pm \text { S.E.M.) }\end{array}$} & \multicolumn{2}{|c|}{ Day 5 Blastocysts* } & \multicolumn{2}{|c|}{ Day 7 Blastocysts } \\
\hline & & $\begin{array}{c}\text { Formed } \\
(\% \pm \text { S.E.M.) }\end{array}$ & $\begin{array}{c}\text { Total cell } \\
\text { number }\end{array}$ & $\begin{array}{c}\text { Formed } \\
(\% \pm \text { S.E.M.) }\end{array}$ & $\begin{array}{c}\text { Total cell } \\
\text { number }\end{array}$ \\
\hline Control & $\begin{array}{c}121 / 181 \\
(66.8 \pm 5.2)^{\mathrm{A}}\end{array}$ & $\begin{array}{c}83 / 306 \\
(27.1 \pm 9.2)^{\mathrm{A}}\end{array}$ & $\begin{array}{c}32.1 \pm 1.1^{\mathrm{A}} \\
(\mathrm{n}=73)\end{array}$ & $\begin{array}{c}55 / 181 \\
(30.4 \pm 0.7)^{\mathrm{A}}\end{array}$ & $\begin{array}{c}41.5 \pm 1.6^{\mathrm{A}} \\
(\mathrm{n}=32)\end{array}$ \\
\hline $0.5 \mu \mathrm{M}$ Res. & $\begin{array}{c}139 / 171 \\
(81.3 \pm 2.7)^{\mathrm{B}}\end{array}$ & $\begin{array}{c}102 / 294 \\
(34.7 \pm 9.8)^{\mathrm{B}}\end{array}$ & $\begin{array}{c}35.8 \pm 0.9^{B} \\
\quad(n=85)\end{array}$ & $\begin{array}{c}77 / 171 \\
(45.0 \pm 2.7)^{\mathrm{B}}\end{array}$ & $\begin{array}{c}45.4 \pm 1.4^{\mathrm{A}} \\
(\mathrm{n}=40)\end{array}$ \\
\hline
\end{tabular}

A, B Different superscripts indicate significant differences $(\mathrm{P}<0.05)$. *For the analysis, Day 5 Blastocysts were collected from separate experiments 


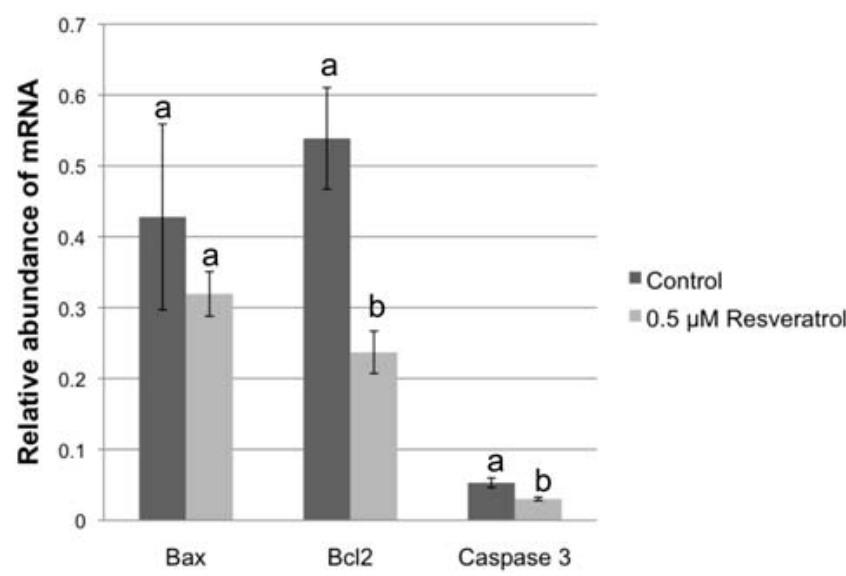

Fig. 1. Expression of apoptosis-related genes in parthenogenetic blastocysts developed in the presence of resveratrol. Different superscript letters indicate statistically significant differences between treatment groups $(\mathrm{P}<0.05)$.

supplementation, the percentage of cleaved embryos increased from $66.8 \pm 5.2 \%$ to $81.3 \pm 2.7$ and blastocyst formation at the end of the 7-day culture period improved from $30.4 \pm 0.7$ to $45.0 \pm 2.7$ $(\mathrm{P}<0.05)$. The average cell numbers of the developing parthenogenetic blastocysts are also shown in Table 3. Control and $0.5 \mu \mathrm{M}$ resveratrol-treated day 7 blastocysts had a total of $42.4 \pm 2.1$ and $44.0 \pm 1.9$ cells, respectively; the difference was not statistically significant. However, when in separate experiments development was evaluated after only 5 days of culture, the average cell number in the resveratrol-treated blastocysts was significantly higher than that in the control group ( $35.8 \pm 1.0$ vs. $32.1 \pm 1.1 ; \mathrm{P}<0.05$ ).

Results from real-time RT-PCR indicated significant changes in the expression levels of apoptosis-related genes as a result of incubation with resveratrol; the data are shown in Fig. 1. Transcript levels of the Bcl-2 and Caspase-3 genes were lower in parthenogenetic embryos cultured with $0.5 \mu \mathrm{M}$ resveratrol compared to control embryos $(\mathrm{P}<0.05)$. The expression level of the Bax gene was not different between control and resveratrol-treated $(0.5 \mu \mathrm{M})$ embryos. The results of the TUNEL assay demonstrated that there was no difference in DNA fragmentation after resveratrol treatment (Table 4); the average number of nuclei showing DNA fragmentation was similar in the control and resveratrol-treated groups.

Embryos produced by in vitro fertilization also showed better development when cultured in the presence of $0.5 \mu \mathrm{M}$ resveratrol (Table 5). This experiment was performed in seven replications. In the control group the frequency of blastocyst formation was 8.6 $\pm 2.1 \%$ whereas a significantly higher percentage of resveratroltreated embryos formed blastocysts by the end of the 7-day culture period (13.3 \pm 1.1$)$. In addition, resveratrol treatment also affected cleavage frequency. A higher percentage of 2-cell embryos were registered in the resveratrol-treated group as compared to the nontreated control (56.5 \pm 5.9 vs. $67.1 \pm 3.3)$. As shown in Table 5, by day 7 following fertilization the average total cell number was also higher in IVF blastocysts that developed in the presence of resveratrol than that in the control embryos (43.2 \pm 1.7 vs. $37.1 \pm 2.4$; $\mathrm{P}<0.05)$

\section{Discussion}

This study demonstrated that resveratrol had a marked effect on the in vitro development of preimplantation pig embryos. Supplementation of the culture medium with $0.5 \mu \mathrm{M}$ resveratrol enhanced blastocyst formation, increased total cell numbers of parthenogenetic and IVF blastocysts and affected events related to programmed cell death in the developing embryos.

No previous reports are available regarding the influence of resveratrol on preimplantation embryo development. In cell culture studies, resveratrol had a dose-dependent effect on the proliferation of cultured cells: at high concentrations resveratrol exerted an antiproliferation effect and induced apoptosis whereas at low concentrations it promoted cell division in various human cell lines $[14,18]$. In this study a similar effect of resveratrol on parthenogenetic pig embryos was observed. High levels $(25 \mu \mathrm{M})$ of resveratrol in the culture medium had toxic side effects and were detrimental to the developing parthenogenetic embryos. However,

Table 4. DNA fragmentation in day 7 parthenogenetic embryos as determined by the TUNEL assay

\begin{tabular}{lcc}
\hline $\begin{array}{l}\text { Resveratrol } \\
\text { concentration }\end{array}$ & No. of blastocysts & $\begin{array}{c}\text { Percentage of apoptotic nuclei } \\
\text { (mean } \pm \text { S.E.M.) }\end{array}$ \\
\hline $0 \mu \mathrm{M}$ (control) & 32 & $12.6 \pm 1.6 \%$ \\
$0.5 \mu \mathrm{M}$ & 40 & $11.5 \pm 1.1 \%$ \\
\hline
\end{tabular}

Table 5. Effect of resveratrol on the development of embryos produced by in vitro fertilization

\begin{tabular}{lcccc}
\hline $\begin{array}{l}\text { Resveratrol } \\
\text { concentration }\end{array}$ & $\begin{array}{c}\text { No. of } \\
\text { embryos }\end{array}$ & $\begin{array}{c}\text { No. of embryos } \\
\text { cleaved } \\
(\% \pm \text { S.E.M.) }\end{array}$ & $\begin{array}{c}\text { No. of blastocysts } \\
(\% \pm \text { S.E.M.) }\end{array}$ & $\begin{array}{c}\text { No. of cells in } \\
\text { blastocysts } \\
\text { (mean } \pm \text { S.E.M. })\end{array}$ \\
\hline $0 \mu \mathrm{M}$ (control) & 370 & $209(56.5 \pm 5.9)^{\mathrm{A}}$ & $32(8.6 \pm 2.1)^{\mathrm{A}}$ & $37.1 \pm 2.4^{\mathrm{A}}$ \\
$0.5 \mu \mathrm{M}$ & 368 & $247(67.1 \pm 3.3)^{\mathrm{B}}$ & $49(13.3 \pm 1.1)^{\mathrm{B}}$ & $43.2 \pm 1.7^{\mathrm{B}}$ \\
\hline
\end{tabular}

A, B Different superscripts indicate significant differences $(\mathrm{P}<0.05)$. Blastocyst development was evaluated after 7 days in culture. 
lower concentrations tended to be beneficial and a concentration of $0.5 \mu \mathrm{M}$ increased blastocyst formation and supported cell proliferation in the parthenotes. These results are consistent with the proproliferation characteristic of resveratrol reported in the abovementioned studies [14, 18]. Moreover, reduced blastocyst formation in the presence of elevated concentrations of resveratrol seems to support the notion that resveratrol at high levels induces apoptosis in cells [19], although this was not directly evaluated in the present study.

Apoptosis in preimplantation embryos can be induced by suboptimal culture conditions in vitro, and its incidence in the developing embryos can be correlated to embryo quality [20-22]. Apoptotic activity has recently been demonstrated in parthenogenetic porcine preimplantation embryos [23, 24]. Although no reports are available regarding the effects of resveratrol on embryos, the results of studies that focused on the physiological action of resveratrol in cultured cells implied a role for resveratrol in affecting early embryo development. According to published data the action of resveratrol in cell cultures depended on the cell types and the concentration of resveratrol used. In various cancer cell lines resveratrol activated p53 by phosphorylation which in turn suppressed proliferation of the cells [25-27]. Moreover, elevated transcript levels of genes related to apoptosis such as Bak, Bcl-2, and p21 were reported in those studies. On the other hand, in rheumatoid fibroblast-like synoviocytes resveratrol induced programmed cell death but the levels of Bax and Bcl-2 were not changed. Instead, resveratrol triggered the mitochondria-related apoptotic pathway by activating Bid cleavage via Caspase-8 [28]. Despite such inconsistencies most studies support the idea that above a certain threshold level resveratrol induces apoptosis and stimulates apoptosis-related genes characterizing resveratrol as an anti-cancer reagent [19, 29, 30].

In the present study, supplementation of the culture medium with low $(0.5 \mu \mathrm{M})$ concentrations of resveratrol resulted in decreased levels of Bcl-2 transcripts in the parthenogenetic blastocysts suggesting that resveratrol suppresses the expression of prosurvival genes of the intrinsic apoptosis pathway in embryos. However, the expression level of Bax, a pro-apoptosis gene in the intrinsic pathway was not altered. Thus, it seems that $0.5 \mu \mathrm{M}$ resveratrol does not stimulate programmed cell death in pig embryos. In addition to its role in regulating apoptosis, Bcl-2 is also known as an antiproliferative gene that regulates the cell cycle by driving cells into the G0 phase and delaying the G0 to S phase transition [31]. Lower expression of $\mathrm{Bcl}-2$ in resveratrol-treated blastocysts may reflect faster G0 to S phase transition leading to a higher proliferation rate as indicated by higher total cell numbers in these embryos. Caspase-3 expression was also downregulated in blastocysts that developed in the presence of resveratrol suggesting a decreased apoptotic activity in the embryos. Caspase-3 is an effector caspase located downstream of $\mathrm{Bcl}-2$ in the apoptosis pathway. Based on these results low levels of resveratrol seem to suppress apoptotic events in preimplantation embryos at least at the transcript level. A similar anti-apoptosis effect of resveratrol, i.e. the suppression of caspase activity was reported in human keratinocyte cell lines. Treatment with resveratrol could protect the cells from cell death induced by ultraviolet $B$ irradiation by attenuating the caspase pathway [32].

Results from the TUNEL assay indicate that resveratrol does not induce DNA fragmentation in embryos. Fragmentation of DNA is associated with late stage apoptosis. Although the TUNEL assay also labels the fragmented DNA of necrotic cells it is generally accepted to be a good indicator of late-stage apoptosis [22]. Based on our results we conclude that $0.5 \mu \mathrm{M}$ resveratrol in the culture system has a pro-proliferative (Bcl-2 downregulation) and antiapoptotic (Caspase-3 downregulation) effect in parthenogenetic porcine embryos. This is consistent with results obtained during a study in which stress response of embryos after resveratrol treatment was investigated. When apoptosis was induced by ethanol in mouse blastocysts, resveratrol had a protective effect on the embryos [33]. In addition, resveratrol-treated blastocysts were resistant to ethanol-induced apoptosis and showed lower expression of Caspase- 3 and Caspase- 9 when compared to non-treated embryos.

Enhanced development of IVF embryos in the presence of 0.5 $\mu \mathrm{M}$ resveratrol implies that the effect of resveratrol is not limited to parthenogenetic embryos only. The frequency of cleavage, blastocyst formation and the total cell number was also higher in resveratrol-treated IVF embryos suggesting that resveratrol positively affected embryonic development after fertilization. The percentage of embryos that reached the blastocyst stage after in vitro fertilization was relatively low; seasonal and/or boar effects may be accountable for this limited efficiency (typically the frequency of blastocyst formation following in vitro fertilization is around $15 \%$ in our laboratory [our unpublished results]). Nevertheless, the data obtained from IVF embryos supports our notion that resveratrol is beneficial for embryonic development in vitro.

The molecular mechanism by which resveratrol exerts its effect on preimplantation embryos is not clear. One potential mechanism of action for resveratrol can be speculated from its structure. Resveratrol shows structural similarity to diethylstilbestrol (DES; 4 , 4'-dihydroxy-trans-alpha, beta-diethylstilbene), a synthetic estrogen that was shown to bind to human estrogen receptors in binding assays [34]. The same study also demonstrated that resveratrol induced proliferation of various human cell lines by stimulating the estrogen receptor in a dose dependent manner. The estrogen receptor has long been implicated in the regulation of cellular development [35] and its expression was shown in preimplantation pig embryos [36]. In addition, in another report low concentrations (5-10 $\mu \mathrm{M})$ of resveratrol induced S-phase entry and this pro-proliferation effect was limited to cells possessing androgen receptors [18]. These results suggest a relationship between resveratrol and steroids and seem to support a hypothesis whereby low concentrations of resveratrol may act as an agonist for specific steroid hormone receptors during preimplantation embryo development in vitro.

In conclusion, treatment of pig embryos with $0.5 \mu \mathrm{M}$ resveratrol has a beneficial effect on preimplantation development leading to enhanced blastocyst formation and improved embryo quality in terms of total cell number in the blastocysts. The treatment also resulted in decreased expression of the Bcl-2 and Caspase-3 genes; however, understanding the mechanisms involved needs further investigations. 


\section{Acknowledgements}

The authors wish to thank the Indiana Packers Corporation (Delphi, IN, USA) for donating the pig ovaries.

\section{References}

1. Rizos D, Clemente M, Bermejo-Alvarez $\mathbf{P}$, de La Fuente J, Lonergan $\mathbf{P}$, GutierrezAdan A. Consequences of in vitro culture conditions on embryo development and quality. Reprod Domest Anim 2008; 43 (Suppl 4): 44-50.

2. Duranthon V, Watson AJ, Lonergan P. Preimplantation embryo programming: transcription, epigenetics, and culture environment. Reproduction 2008; 135: 141-150.

3. Baur JA, Sinclair DA. Therapeutic potential of resveratrol: the in vivo evidence. Nat Rev Drug Discov 2006; 5: 493-506.

4. Soleas GJ, Diamandis EP, Goldberg DM. Resveratrol: a molecule whose time has come? And gone? Clin Biochem 1997; 30: 91-113.

5. Kimura Y, Okuda $\mathbf{H}$, Arichi S. Effects of stilbenes on arachidonate metabolism in leukocytes. Biochim Biophys Acta 1985; 834: 275-278.

6. Jayatilake GS, Jayasuriya H, Lee ES, Koonchanok NM, Geahlen RL, Ashendel CL, McLaughlin JL, Chang CJ. Kinase inhibitors from Polygonum cuspidatum. J Nat Prod 1993; 56: 1805-1810.

7. Jang M, Cai L, Udeani GO, Slowing KV, Thomas CF, Beecher CW, Fong HH, Farnsworth NR, Kinghorn AD, Mehta RG, Moon RC, Pezzuto JM. Cancer chemopreventive activity of resveratrol, a natural product derived from grapes. Science 1997; 275 : 218-220.

8. Pirola L, Frojdo S. Resveratrol: one molecule, many targets. IUBMB Life 2008; 60: 323332.

9. Kundu JK, Surh YJ. Cancer chemopreventive and therapeutic potential of resveratrol: mechanistic perspectives. Cancer Lett 2008; 269: 243-261.

10. Howitz KT, Bitterman KJ, Cohen HY, Lamming DW, Lavu S, Wood JG, Zipkin RE, Chung P, Kisielewski A, Zhang LL, Scherer B, Sinclair DA. Small molecule activators of sirtuins extend Saccharomyces cerevisiae lifespan. Nature 2003; 425: 191-196.

11. Wood JG, Rogina B, Lavu S, Howitz K, Helfand SL, Tatar M, Sinclair D. Sirtuin activators mimic caloric restriction and delay ageing in metazoans. Nature 2004; 430: 686689.

12. Baur JA, Pearson KJ, Price NL, Jamieson HA, Lerin C, Kalra A, Prabhu VV, Allard JS, Lopez-Lluch G, Lewis K, Pistell PJ, Poosala S, Becker KG, Boss O, Gwinn D, Wang M, Ramaswamy S, Fishbein KW, Spencer RG, Lakatta EG, Le Couteur D, Shaw RJ, Navas P, Puigserver P, Ingram DK, de Cabo R, Sinclair DA. Resveratrol improves health and survival of mice on a high-calorie diet. Nature 2006; 444: 337-342.

13. Clement M, Hirpara JL, Chawdhury S, Pervaiz S. Chemopreventive agent resveratrol, a natural product derived from grapes, triggers CD95 signaling-dependent apoptosis in human tumor cells. Blood 1998; 92: 996-1002.

14. Szende B, Tyihak E, Kiraly-Veghely Z. Dose-dependent effect of resveratrol on proliferation and apoptosis in endothelial and tumor cell cultures. Exp Mol Med 2000; 32: 88-92.

15. Mizutani K, Ikeda K, Kawai Y, Yamori Y. Resveratrol stimulates the proliferation and differentiation of osteoblastic MC3T3-E1 cells. Biochem Biophys Res Commun 1998; 253: 859-863

16. Abeydeera LR, Wang WH, Cantley TC, Rieke A, Prather RS, Day BN. Presence of epidermal growth factor during in vitro maturation of pig oocytes and embryo culture can modulate blastocyst development after in vitro fertilization. Mol Reprod Dev 1998; 51: 395-401.

17. Mohana Kumar B, Song HJ, Cho SK, Balasubramanian S, Choe SY, Rho GJ. Effect of histone acetylation modification with sodium butyrate, a histone deacetylase inhibitor, on cell cycle, apoptosis, ploidy and gene expression in porcine fetal fibroblasts. Reprod Dev 2007; 53: 903-913.

18. Kuwajerwala N, Cifuentes E, Gautam S, Menon M, Barrack ER, Reddy GPV. Resveratrol induces prostate cancer cell entry into $S$ phase and inhibits DNA synthesis. Cancer Res 2002; 62: 2488-2492.

19. Park JW, Choi YJ, Suh SI, Baek WK, Suh MH, Jin IN, Min DS, Woo JH, Chang JS, Passaniti A, Lee YH, Kwon TK. Bcl-2 overexpression attenuates resveratrol-induced apoptosis in U937 cells by inhibition of caspase-3 activity. Carcinogenesis 2001; 22 1633-1639.

20. Betts DH, King WA. Genetic regulation of embryo death and senescence. Theriogenology 2001; 55: 171-191.

21. Levy RR, Cordonier H, Czyba JC, Guerin JF. Apoptosis in preimplantation mammalian embryo genetics. Ital J Anat Embryol 2001; 106 (Suppl 2): 101-108.

22. Fabian D, Koppel J, Maddox-Hyttel P. Apoptotic process during mammalian preimplantation development. Theriogenology 2005; 64: 213-221.

23. Hao Y, Lai L, Mao J, Im GS, Bonk A, Prather RS. Apoptosis in parthenogenetic preimplantation porcine embryos. Biol Reprod 2004; 70: 1644-1649.

24. Lee K, Hyslop JM, Nanassy L, Machaty Z. Incidence of apoptosis in parthenogenetic porcine embryos generated by using protein kinase or protein synthesis inhibitor Anim Reprod Sci 2009; 112: 261-272.

25. Hsieh TC, Juan G, Darzynkiewicz Z, Wu JM. Resveratrol increases nitric oxide synthase, induces accumulation of p53 and p21(WAF1/CIP1), and suppresses cultured bovine pulmonary artery endothelial cell proliferation by perturbing progression through S and G2. Cancer Res 1999; 59: 2596-2601.

26. She QB, Bode AM, Ma WY, Chen NY, Dong Z. Resveratrol-induced activation of p53 and apoptosis is mediated by extracellular signal-regulated protein kinases and p38 kinase. Cancer Res 2001; 61: 1604-1610.

27. Narayanan BA, Narayanan NK, Re GG, Nixon DW. Differential expression of gene induced by resveratrol in LNCAP cells: p53-mediated molecular targets. Int J Cancer 2003; 104: 204-212.

28. Byun HS, Song JK, Kim YR, Piao L, Won M, Park KA, Choi BL, Lee H, Hong JH, Park J, Seok JH, Lee YJ, Kang SW, Hur GM. Caspase-8 has an essential role in resveratrol-induced apoptosis of rheumatoid fibroblast-like synoviocytes. Rheumatology 2008; 47: 31-38.

29. Mahyar-Roemer M, Kohler $\mathbf{H}$, Roemer $\mathbf{K}$. Role of Bax in resveratrol-induced apoptosis of colorectal carcinoma cells. BMC Cancer 2002; 2: 27-36.

30. Signorelli P, Ghidoni R. Resveratrol as an anticancer nutrient: molecular basis, open questions and promises. J Nutr Biochem 2005; 16: 449-466.

31. Janumyan YM, Sansam CG, Chattopadhyay A, Cheng N, Soucie EL, Penn LZ Andrews D, Knudson CM, Yang E. Bcl-xL/Bcl-2 coordinately regulates apoptosis, cell cycle arrest and cell cycle entry. EMBO I 2003; 22: 5459-5470.

32. Park K, Lee JH. Protective effects of resveratrol on UVB-irradiated HaCaT cells through attenuation of the caspase pathway. Oncol Rep 2008; 19: 413-417.

33. Huang LH, Shiao NH, Hsuuw YD, Chan WH. Protective effects of resveratrol on ethanol-induced apoptosis in embryonic stem cells and disruption of embryonic development in mouse blastocysts. Toxicology 2007; 242: 109-122.

34. Gehm BD, McAndrews JM, Chien PY, Jameson JL. Resveratrol, a polyphenolic compound found in grapes and wine, is an agonist for the estrogen receptor. Proc Nat Acad Sci USA 1997; 94: 14138-14143.

35. Clark JH, Markaverich BM. Actions of ovarian steroid hormones. In: Knobil E, Nei JD, Ewing LL, Greenwald GS, Markert CL, Pfaff DW (eds.), The Physiology of Reproduction. New York: Raven Press; 1988: 675-724.

36. Ying C, Hsu WL, Hong WF, Cheng WT, Yang Y. Estrogen receptor is expressed in pig embryos during preimplantation development. Mol Reprod Dev 2000; 55: 83-88. 